\title{
Risk-Based Due Diligence, Climate Change, Human Rights and the Just Transition
}

\author{
Claire Bright ${ }^{1, *}$ and Karin Buhmann ${ }^{2}$
}

1 Department of Law, Nova University, 1099-032 Lisbon, Portugal

2 Department of Management, Society and Communication, Copenhagen Business School, DK-2000 Frederiksberg, Denmark; kbu.msc@cbs.dk

* Correspondence: claire.bright@novalaw.unl.pt

check for

updates

Citation: Bright, C.; Buhmann, K. Risk-Based Due Diligence, Climate Change, Human Rights and the Just Transition. Sustainability 2021, 13, 10454. https://doi.org/10.3390/ su131810454

Academic Editors: Olga Martin-Ortega, Valerie Nelson, Renginee G. Pillay and

Fatimazahra Dehbi

Received: 9 June 2021

Accepted: 30 July 2021

Published: 20 September 2021

Publisher's Note: MDPI stays neutral with regard to jurisdictional claims in published maps and institutional affiliations.

Copyright: (c) 2021 by the authors. Licensee MDPI, Basel, Switzerland. This article is an open access article distributed under the terms and conditions of the Creative Commons Attribution (CC BY) license (https:/ / creativecommons.org/licenses/by/ $4.0 /)$.

\begin{abstract}
Climate change has been described as one of the greatest threats to people and the planet. Its impacts affect virtually the entire spectrum of internationally recognised human rights as well as the environment in and of itself. In relation to human rights, there is a growing consensus that companies should exercise human rights due diligence in order to identify and prevent their actual and potential adverse impacts. However, the relevance and implications of the concept of the due diligence have not yet fully been analysed in relation to climate change. In this paper, we explore the concept of risk-based due diligence, which builds on the concept of human rights due diligence but extends it to other areas such as the environment. Through a review of recent regulatory developments as well as case-law and other grievances, we analyse the three facets of risk-based due diligence for climate change-prevention, mitigation and remediation. We consider both the short term as well as the longer-term human rights and environmental implications of companies' climate-related impacts, as well as those resulting from the company's contributions to the green transition. We argue that risk-based due diligence offers an under-explored but important dual function: providing the operational means through which companies can identify and address the climate-related human rights and environmental impacts with which they may be involved, whilst also taking into consideration the human rights implications of their climate mitigation strategies and contributions to the just transition.
\end{abstract}

Keywords: human rights due diligence; climate change; risk-based due diligence; just transition

\section{Introduction}

Climate change is a major challenge to sustainable social, environmental and economic development across the globe. It has been well documented that climate change threatens the entire ecosystem and increases the occurrence, inter alia, of insect-born as well as water-related and foodborne diseases, wildfires, salination, raised water levels as well as extreme weather events such as drought, extreme precipitation, storms and hurricanes [1]. In addition to the environmental impacts in and of themselves of such events, they also adversely impact the full enjoyment of human rights, including the right to life, health, food, housing, an adequate standard of living, land and employment [2]. Many of these adverse impacts are disproportionately felt by the poor, women, children, migrants, persons with disabilities, minorities, Indigenous people and others in vulnerable situations, particularly those living in geographically vulnerable developing countries [2].

The 'green' transition to a low-carbon economy is a key aspect of combating climate change. In addition to actions by governments and individuals, the green transition involves proactive steps as well as opportunities for business enterprises, recognised both explicitly and implicitly in the Agenda 2030 with 17 Sustainable Development Goals (SDG) [3] and in the Paris Climate Change Agreement [4].

Recently, concerns relating to current and future climate change impacts have given rise to several court cases and other grievances grounded on allegations of inaction by both 
the public and the private sector. They rely on the argument that governments and business enterprises need to understand their climate-related impacts and respond adequately in order to reduce their contributions to climate change. In this respect, the concept of human rights due diligence-as originally set out in the UN Guiding Principles on Business and Human Rights-has increasingly been put forward as the means for companies to fulfil their human rights responsibilities in relation to climate change [5] However, there is a knowledge gap with regard to the precise implications of a human rights due diligence in relation to climate change. In particular, little attention has been turned to the human rights implications of climate mitigation and adaption strategies and the role that the concept of due diligence could play in this respect in order to ensure a just transition. This paper aims to contribute to filling these knowledge gaps by exploring risk-based due diligence-which builds on the concept of human rights due diligence, but extends it to include other issues beyond human rights only such as the environment $[6,7]$ as an approach for companies to understand and address their impacts related to climate change. This paper argues that risk-based due diligence for climate change can play a dual function: providing the operational means through which companies can identify and address the climate-related human rights and environmental impacts with which they may be involved, whilst also taking into consideration the human rights implications of their climate mitigation strategies and contributions to climate change mitigation. As we show, it offers an important approach for companies in the green energy sector to contribute to the urgent transition for the benefit of humanity in the medium and longer term in a manner that respects human rights of those currently affected or at risk of being adversely affected due to the expansion of green energy production.

The methodology used relies on: (1) a regulatory review of the relevant instruments in order to analyse the concept of risk-based due diligence, the arguments on which it rests and its relevance in the context of climate change; (2) a review of key court decisions and specific instances before the OECD National Contact Points in order to identify case-law based expectations for companies to identity and address their climate change impacts; and (3) a socio-legal review of the connection between green energy development to help mitigate climate change and adverse human rights impacts which may arise out of such activities. Through these approaches we identify (1) the fundamental normative substance of risk-based due diligence; (2) the legal implications of case-law for companies in relation to their short, medium and long-term climate-related human rights and environmental impacts; and (3) the significance of due diligence for companies in the green energy sector to identity and manage actual and potential adverse impacts on workers and host communities. This enables us to discuss and conclude on the pertinence of risk-based due diligence for companies to identify and manage human rights or environmental impacts, whether related to companies' general role in advancing climate change or to their core business activities related to climate change mitigation.

The article proceeds as follows: Section 2 briefly explains the causes and effects of climate change and global warming, and analyses the role of business in regard to actual and potential adverse human rights and environmental impacts. Section 3 explores the concept of risk-based due diligence, its background, and its application as a management approach for business enterprises of all sizes and forms to identify and manage their adverse impacts. Section 4 details the implications of risk-based due diligence for climate change in relation to its three facets-prevention, mitigation and remediation-through examples of court cases and other grievances concerned as well as regulatory developments (both in terms of the soft law and hard law).

\section{Climate Change, Business Impacts and Human Rights}

Global warming is a key aspect of the climate change that the world has been experiencing for some time, with long-term rise in temperatures globally. While some changes in global temperatures occur naturally over long spans of time, it has been acknowledged that the significant rise in temperatures that the world has experienced in recent decades is 
due to increased concentrations of greenhouse gases in the atmosphere caused by human activities $[1,8]$. This includes, in particular, industrial activities, such as the burning of fossil fuels (oil, gas, coal), deforestation and clearing of trees and bushes for farming or industry, agriculture (and notably livestock like sheep and cattle that produce methane, a powerful greenhouse gas), farming of soil which can release stored greenhouse gases, and use of fertilizers that release greenhouse gases [9].

The role of companies as the main drivers of global warming has been widely acknowledged. For instance, a study by climatologist Richard Heede which aggregated historical emissions according to carbon producing entities found that nearly two-thirds of global emissions from 1850 to 2010 can be traced to 90 companies in the oil, coal and gas industries [10]. Similarly, a UN report noted that in 2015, companies accounted for $91 \%$ of global industrial greenhouse emissions and 70\% of all human-made emissions [11].

Climate science has highlighted the pressing need to stabilise greenhouse gas concentrations in the atmosphere at a level that would prevent dangerous 'anthropogenic interference with the climate system' [12]. The Intergovernmental Panel on Climate Change (IPCC) has warned against the risks of dangerous, irreversible climate change if global warming exceeds $2{ }^{\circ} \mathrm{C}$ [13]. The latest report of the IPCC highlighted that human activities have contributed to global warming at an unprecedented rate in the last 2000 years [14], and that global warming is now accelerating with global temperature expected to reach or exceed $1.5{ }^{\circ} \mathrm{C}$ warming over the next 20 years [14]. Against this backdrop, it calls for strong and sustained reductions in $\mathrm{CO}_{2}$ emissions.

The Paris agreement was adopted in 2015 with the aim to strengthen the global response to the threat of climate change, and included a commitment by the State Parties to keep the increase in the 'global average temperature to well below $2{ }^{\circ} \mathrm{C}$ above pre-industrial levels' by 2100 and to pursue efforts 'to limit the temperature increase to $1.5{ }^{\circ} \mathrm{C}$ above pre-industrial levels, recognizing that this would significantly reduce the risks and impacts of climate change' [4]. The Paris Agreement also invites the non-State Party stakeholdersincluding the private sector and financial institutions- 'to scale up their efforts and support actions to reduce emissions and/or to build resilience and decrease vulnerability to the adverse effects of climate change and demonstrate these efforts' [4].

Whilst States have traditionally been pictured as the main duty-bearers of human rights and environmental obligations requiring them, inter alia, to take effective measures to prevent and redress climate impacts, UN expert bodies have affirmed that businesses are also duty-bearers. In particular, they have acknowledged that the responsibilities of businesses in relation to human rights and climate change entail that companies should be 'accountable for their climate impacts and participate responsibly in climate change mitigation and adaptation efforts with full respect for human rights' [15]. Complying with human rights in the context of climate change therefore requires both States and private actors to ensure that their actions do not worsen climate change, and to find more environmentally sustainable modes of production and consumption [16].

Ironically, climate change also presents opportunities for business. The turn to lowcarbon energy creates new business opportunities for companies involved in innovation, development, construction and/or renewable energy, such as wind, solar and hydro-power, batteries for energy storage. However, such activities can also cause adverse human rights impacts, especially for workers and neighbouring communities. The preamble of the Paris Agreement recognizes this risk and the need to address it by referring to the human rights responsibilities in the context of climate mitigation [4]:

Parties should, when taking action to address climate change, respect, promote and consider their respective obligations on human rights, the right to health, the rights of indigenous peoples, local communities, migrants, children, persons with disabilities and people in vulnerable situations and the right to development, as well as gender equality, empowerment of women and intergenerational equity.

Moreover, the Agenda 2030, which set forth 17 Sustainable Development Goals (SDGs), also recognises that risks to human rights and the environment must be addressed [3]. In 
particular, SDG 13 on urgent action to combat climate change and its impacts, and SDG 7 on access to affordable, reliable, sustainable and modern energy for all, contribute to driving up activities to support the implementation and production of facilities and technical solutions for energy that is sustainable from a climate change mitigation perspective. SDG 17 call for partnerships to implement the SDGs and the implementation provisions (para. 67) explicitly notes that SDG implementation must not cause harm to human rights and the environment, and refer inter alia to the UN (United Nations) Guiding Principles on Business and Human Rights [17]. The latter provide detailed guidance for companies on how to fulfil their responsibility to respect human rights through the exercise of human rights due diligence, as explained in the following section.

\section{From Human Rights Due Diligence to Risk-Based Due Diligence}

Originally developed in relation to the adverse impacts of business activity on human rights, the concept of human rights due diligence has progressively been extended to other existing or potential adverse impacts, including those on the environment and climate change under the term 'risk-based due diligence'. Both concepts will be analysed in turn.

\subsection{The Concept of Human Rights Due Diligence}

The concept of human rights due diligence originates from two interrelated instruments from the UN: The 'Respect, Protect and Remedy' Framework (UN Framework) [17] and the UN Guiding Principles (UNGPs) on Business and Human Rights [18] which operationalize the UN Framework. These instruments rest around 3 pillars: (1) the state duty to protect against human rights abuses committed by third parties, including by business, affecting individuals and communities within their territory or jurisdiction; (2) the corporate responsibility to respect human rights; and (3) effective access to remedy for victims. Such corporate responsibility to respect covers all internationally recognised human rights and exists over and above compliance with national laws and regulations protecting human rights. It is independent of States' abilities and/or willingness to fulfil their own human rights obligations [18].

As noted by the UN Framework, governments define the scope of legal compliance, but 'the broader scope of the responsibility to respect is defined by social expectations-as part of what is sometimes called a company's social licence to operate' [17]. The UN Framework and UNGPs observe that the responsibility to respect human rights is a global standard of expected conduct for all business enterprises wherever they operate, and that discharging the corporate responsibility to respect human rights requires human rights due diligence $[17,18]$. In this sense, human rights due diligence is core to the corporate responsibility to respect human rights under Pillar 2. It refers to a management process that companies are expected to put in place in order to identify, prevent and address adverse human rights impacts. Human rights due diligence is contextual and involves a series of steps that a company must take to become aware, prevent and address harmful impacts on the enjoyment of human rights by rights-holders such as workers and local communities [18]. The human rights due diligence expectations apply to all companies globally, regardless of form and size, and reach throughout their value chain. The process comprises four components: assessing actual and potential adverse impacts, integrating and acting upon the findings, tracking the effectiveness of responses, and communicating on how impacts are addressed ([18]. Moreover, remediation must be provided for in case harmful impacts do occur [18].

Leaning on impact assessment theory and practice as integrated in other types of societal risk-identification, such as for environmental purposes, the UN Framework and the UNGPs established human rights impact assessments as a cornerstone of the first component of the human rights due diligence process for companies to identify and understand how existing and proposed projects or activities may affect human rights. Subsequently, companies should 'integrate the findings from their impact assessments' and 'take appropriate action' $[17,18]$. Appropriate action will vary according to, inter alia, the 
degree of involvement of the company in the human rights harm. In particular, companies may be involved in human rights harms in three ways: they may cause adverse impacts, they may contribute to adverse impacts through their own activities, or they may be directly linked to the adverse impacts [18]. A company causes harm where its own activities (its actions or omissions) on their own "remove or reduce" a person's (or group of persons') ability to enjoy human rights' [19] Appropriate action consists of taking 'the necessary steps to cease or prevent the impact' [18]. A company contributes to an impact if its actions and decisions influenced another entity 'in such a way as to make the adverse human rights impact more likely' [19]. Appropriate action requires the company to 'take the necessary steps to cease or prevent its contribution and use its leverage to mitigate any remaining impact to the greatest extent possible' [18]. A direct linkage refers to a situation in which there is a direct link between a company's operations, products or services by its business relationships and an adverse human rights impact, even if it has not caused or contributed to those impacts. In this situation, appropriate action requires the exercise of influence (referred to as leverage in the BHR context) to encourage and help the entity causing the harm to mitigate and/or cease it [18]. Where the company lacks leverage, it should seek ways to increase it. Leverage can be applied individually or in collaboration with others. It may take various forms, such as dialogue, capacity building, or involvement in industry initiatives to address sector-specific issues $[18,20]$.

Intended to be undertaken on an on-going basis, human rights due diligence focuses on risks to people and society, as opposed to standard corporate risk management due diligence, which aims at preventing the legal, technical and financial risks to the company [20]. In this respect, the UNGPs describe meaningful engagement with stakeholders-workers, suppliers, customers and communities-as a core element throughout the human rights due diligence process $[18,20]$. The UNGPs note that the process of identifying and assessing impacts must include meaningful consultation with potentially affected groups and other relevant stakeholders, as appropriate to the size of the business enterprise and the nature and context of the operation. From the commentaries to the UNGPs and the wider context, it is clear that this is not a formal consultation but a process of engagement that involves rights-holders in an active role as experts on potential or actual harmful impacts, even if they may not phrase the risks or impacts in human rights terminology.

The concept of human rights due diligence has been developed in the UN Framework and the UNGPs in relation to human rights and the UNGPs themselves do not contain any explicit reference to the environment or to climate change. However, the UNGP's due diligence approach has been adopted and its application expanded beyond human rights by the several transnational business governance instruments which will be explored next.

\subsection{The Concept of Risk-Based Due Diligence}

The concept of risk-based due diligence-which builds on the concept of human rights due diligence but extends it to other areas such as the environment was set out in the OECD Guidelines for Multinational Enterprises [6] adopted in 1976 and revised in 2011 to align with the UNGPs. The OECD Guidelines are recommendations from adhering governments which apply to companies operating in or out of the 50 adhering countries. They constitute an authoritative and widely endorsed soft law instrument and cover a range of sustainability-related topics, including environment, human rights, labour/industrial relations and anti-corruption, expanding the application of human rights due diligence to most of these issues. The OECD guidelines and accompanying guidance as well as the specific instances from the National Contact Points (NCPs) - whose task is, inter alia, to handle complaints grounded on the non-observance of the OECD Guidelines-provide some insights for the implementation of risk-based due diligence.

In recent years, regulatory developments seeking to implement the risk-based due diligence expectations and turn them into legally binding obligations have emerged at the national and European level [21]. 
In 2017, France was the first country worldwide to adopt a law, the French Duty of Vigilance Law, which requires large companies domiciled in France to put in place, effectively implement and publish a vigilance plan in order to identify and prevent the risks of severe violations of human rights and fundamental freedoms, health and safety and the environment, including climate change, which result from their own activities or the ones of companies under their control as well as the activities of subcontractors or suppliers with whom they have an established commercial relationship [22].

Legislative proposals in this respect are also being put forward in an increasing number of jurisdictions. This includes the Netherlands which adopted the Child Labour Due Diligence Act in 2019 requiring companies selling goods or providing services to the Dutch Market to exercise human rights due diligence in relation to child labour [23], and where a recent legislative initiative which would encompass both human rights and the environment is being discussed [24]. In Norway, the Act on business transparency and work with fundamental human rights and decent work was adopted on the 10 June 2021 [25], creating a corporate duty for large and medium-sized companies domiciled in Norway as well as foreign companies selling products and services in Norway, to conduct due diligence in relation to human rights and decent work throughout all their supply chain, and to provide or cooperate to ensure remedy [26]. In Germany, the Supply Due Diligence Act was approved on the 11th of June 2021, requiring large German companies to exercise due diligence with regard to human rights and certain environmental standards [27]. Other legislative initiatives and campaigns are spurring in many other Member States [28].

At the European level, a proposed legislative agenda on mandatory human rights and environmental due diligence is also being discussed. In this respect, the European Parliament resolution of 10 March 2021 with recommendation to the Commission on corporate due diligence and corporate accountability provides that Member States should lay down rules to ensure that companies carry out due diligence with respect to potential or actual adverse impacts on human rights, the environment and good governance in their operations and business relationships [29]. The draft text defines due diligence as consisting in:

A process put in place by an undertaking in order to identify, assess, prevent, mitigate, cease, monitor, communicate, account for, address and remedy the potential and/or actual adverse impacts on human rights, including social, trade union and labour rights, on the environment, including the contribution to climate change, and on good governance, in its own operations and its business relationships in the value chain.

Human rights and environmental due diligence expectations have also been incorporated by the IFC's performance standards which inform the Equator Principles [29,30]. This is relevant in the current context, because the green transition is recognized to require large amounts of financial capital, which is expected to be provided by financial institutions and institutional investors [31]. The uptake of human rights due diligence by the IFC and other international financial institutions as well as by the EU's Disclosure Regulation [32] highlights the importance for companies to understand and apply risk-based due diligence, taking into account both human rights and environmental impacts in a climate change context. The Disclosure Regulation requires financial product providers to disclose information on certain sustainability factors, specifically environmental, social and human resource issues and issues related to human rights and the fight against corruption and bribery [32]. This must include information on due diligence on harmful impacts on human rights or the environment, i.e., a risk-based due diligence approach. The OECD Guidelines as well as the special instances of the NCPs have clarified in this respect that financial companies are expected to conduct due diligence of their own activities and those of their business relations, such as financed companies [33,34]. Other companies that need access to finance are expected (or required by lending institutions) to do so with regard to their own activities or those of their business relations. 
As a result of these regulatory changes, risk-based due diligence is moving away from the sphere of social expectations and increasingly moving towards the legally binding sphere. Indeed, legally binding obligations are starting to crystalize in relation to all three facets of risk-based due diligence.

\section{The Three Facets of Risk-Based Due Diligence in Relation to Climate Change}

The findings of the 2020 Corporate Human Rights Benchmark—which assessed the human rights disclosure of 230 global companies across various sectors-revealed that 'human rights and climate change are often treated separately' in existing corporate due diligence practices, and highlighted the need for companies to take a holistic view, recognising the interdependence between climate change, social issues and human rights [35]. The report noted that the same companies performed differently on the human rights benchmark and on the climate energy benchmark and considered climate and human rights issues in silos [35]. As detailed below, this lack of holistic approach in corporate practices could be addressed through a comprehensive exercise of risk-based due diligence. In particular, we explore the implications of the concept of risk-based due diligence for climate change in relation to its three interrelated facets-prevention, mitigation and remediation-as well as the expectations which arise from a number of interlinked and interconnected human rights and environmental law principles [15].

\subsection{Risk-Based Due Diligence and Prevention}

The first facet of risk-based due diligence concerns the preventative side, and refers to the positive steps that a company should take to prevent its potential impacts on climate change and its climate-related human rights and environmental impacts. In particular, it requires companies to set measurable objectives and targets.

\subsubsection{The Expectation to Set Measurable Objectives and Targets}

The need for companies take action to prevent 'possibly dangerous, irreversible or catastrophic effects' derives from the precautionary principle-which first emerged in the 1970s and has been enshrined in numerous domestic laws, international treaties on the environment as well as in the Treaty on the Functioning of the European Union [15,36]. The lack of full scientific certainty should not be used as a reason for postponing precautionary measures to anticipate, prevent or minimize the causes of climate change and mitigate its adverse effects. This entails that companies are expected to establish measurable and evidence-based targets in line with the Paris Agreement. This is acknowledged, for instance, by the World Benchmarking Alliance which notes that [36]:

Through on-going social dialogue [...] companies should develop robust, measurable and evidence-based just transition plans that are underpinned by the goals of the Paris Agreement. These plans should cover all business activities and consider both short and long-term objectives. For a just transition plan to be effective, it should be aligned with broader government and stakeholder action on climate resilience.

These target-setting expectations are increasingly being incorporated into the expected risk-based due diligence exercise. At the international level, there are currently no binding international legal obligations on companies to reduce their emissions. However, there are a number of soft law instruments with persuasive authority in this respect. For instance, the OECD Guidelines for Multinational Enterprise provide that as part of their environmental due diligence, companies should establish and maintain a system of environmental management appropriate to the enterprise, including, inter alia [37]:

measurable objectives and, where appropriate, targets for improved environmental performance and resource utilisation, including periodically reviewing the continuing relevance of these objectives; where appropriate, targets should be consistent with relevant national policies and international environmental commitments. 
In 2017, the first ever special instance related to a company's climate policy and to climate-related due diligence in the financial sector was submitted by 4 NGOs to the Dutch OECD National Contact Point (NCP) [38]. The NGOs which submitted the complaint sustained that ING had violated the guidelines in respect of the environment and climate and were requesting ING 'to publish its total carbon footprint (including indirect emissions as a result of INGs loans and investments) and publish ambitious, concrete and measurable emission reduction targets for its loans and investments' [38]. Following the NCP procedure facilitated by the NCP, ING committed to measure the climate alignment of its lending portfolio, and to steer financial flows towards the goals of the Paris Agreement's well-below 2 degrees goal, and to set and publish targets. The Dutch NCP affirmed that [38]:

the OECD Guidelines demand that ING, and other commercial banks, put effort into defining, where appropriate, concrete targets to manage its impact towards alignment with relevant national policies and international environmental commitments. Regarding climate change, the Paris Agreement is currently the most relevant international agreement between states, a landmark for climate change.

Such expectations in relation to target-setting to reduce greenhouse gases emissions and prevent dangerous climate change are also increasingly recognised in judicial decisions.

\subsubsection{Case-Law Developments in Relation to Prevention}

Climate litigation against both States and multinational companies over inadequate climate action has been gaining ground in recent years [15,39]. Examples include the landmark Urgenda decision in which the Dutch Supreme Court found that the Dutch government had breached its obligations under Articles 2 and 8 of the ECHR by not pursuing more ambitious greenhouse emissions reduction target [40].

The climate justice movement and related protests to prevent the harmful effects of climate change have also been spearheaded by children who have filed a number of climate-related cases and complaints seeking to safeguard their interests and the ones of future generations. This includes the 2019 petition submitted by 16 children from 12 countries to the Committee on the Rights of the Child on the basis that the lack of government action on climate crisis constitute a violation of children rights under the UN Conventions on the Rights of the Child [41]. More specifically, the petitioners are asking the UN body which overseas compliance with the treaty to make specific climate-related recommendations to five countries-Argentina, Brazil, France, Germany, and Turkeywhich have all signed the UN Convention on the Rights and the Child and are 'major historical emitters and influential members' of the G20 which makes up $84 \%$ of all global emissions [41]. The petition highlights that each of these countries has 'failed to prevent foreseeable human rights harms caused by climate change by reducing its emissions at the "highest possible ambition"', since none of these countries is on an emission pathway that is consistent with keeping global warming under $3{ }^{\circ} \mathrm{C}$ and have set inadequate emission reduction targets in their Paris Agreement pledges [41]. The petitioners also claim that these countries have 'failed to use all available legal, diplomatic, and economic means to protect children from the life-threatening carbon pollution of the major emitters (China, the U.S., the E.U., and India) and other G20 members' [41]. Such types of arguments are also very relevant in relation to corporate due diligence expectations and are increasingly being raised against companies.

Recently, in a landmark judgment of 26 May 2021 against Royal Dutch Shell (RDS), the District Court of the Hague found that RDS, as the parent company which sets out the corporate policy for the Shell group, has a legal obligation which derives from an 'unwritten standard of care' under Dutch tort law to 'contribute to the prevention of dangerous climate change through the corporate policy it determines for the Shell group' [42]. The court ordered the company to reduce its $\mathrm{CO}_{2}$ emissions by $45 \%$ by 2030 relative to 2019 levels [42] Such recognition of the company's legally binding reduction obligation is what constitutes the ground-breaking character of the decision. It has important implications in relation to due diligence expectations since exercising adequate due diligence is the operational means 
through which a company to fulfil its legal obligation [43]. This is highlighted by the fact that the court made an explicit reference to soft law instruments that had been endorsed by RDS, such as the UN Guiding Principles on Business and Human Rights and the OECD Guidelines for Multinational Enterprises, thereby highlighting their persuasive authority. In particular, the court referred to the UNGPs as a 'universally endorsed' and 'authoritative' soft law instrument 'suitable as a guideline in the interpretation of the unwritten standard of care', regardless of whether or not RDS had committed to the UNGPs [42]. The court also noted that, under the UNGPs, the corporate responsibility to respect human rights exists over and above compliance with national laws and that 'therefore, it is not enough for companies to monitor developments and follow the measures states take' [42]. Furthermore, the court found that there is a 'widespread international consensus that human rights offer protection against the impacts of dangerous climate change and that companies must respect human rights.' [42]. The court also referred to the Urgenda case to deduce that Articles 2 and 8 ECHR offer protection against the consequences of dangerous climate change due to $\mathrm{CO}_{2}$ emissions induced global warming [42].

The court noted that the type of measures expected of a company should be proportionate to its size and affirmed that [42]:

'much may be expected of RDS. RDS heads the Shell group, which consists of about 1100 companies, and operates in 160 countries all over the world. It has a policy-setting position in the Shell group [...] which is a major player on the worldwide market of fossil fuels and is responsible for significant $\mathrm{CO}_{2}$ emissions, which exceed the emissions of many states and which contributes towards global warming and a dangerous climate change in the Netherlands and in the Wadden region [...] with serious and irreversible consequences and risks for the human rights of Dutch residents and the inhabitants of the Wadden region'.

The court distinguished between the $\mathrm{CO}_{2}$ emissions of the Shell group (RDS and the other Shell companies) and the business relations of the Shell group (including end-users). In relation to the former, it was considered that the 'far-reaching control and influence of RDS over the Shell group' meant that RDS' reduction obligations in relation to Scope 1 and Scope 2 emissions which can be ascribed to the Shell companies constituted an obligation of result. With regard to the business relations of the Shell group, including end-users on the other hand, it considered that it was a 'significant best-efforts obligations' through which RDS would be expected to take the necessary steps to remove or prevent the serious risks ensuing from the $\mathrm{CO}_{2}$ emissions generated by the company and to use its influence to limit any lasting consequences as much as possible [42]. It is interesting to note that whilst human rights due diligence is described as an obligation of means in the UNGPs, risk-based due diligence expectations arising out of case-law in relation to climate-change go further by requiring, in certain circumstances, an obligation of result on the basis of specific targets in line with the best available scientific knowledge as embodied in the Paris agreement as will be shown below.

Other examples of climate-related litigation are currently pending in various jurisdictions [39]. In December 2019, 14 French local authorities and 5 French and Ugandan civil society organisations filed an action against Total on the grounds that Total's vigilance plan 'does not ensure that [the company] aligns with a trajectory compatible with the objectives of the Paris Agreement' [44,45]. The claimants relied on the French Duty of Vigilance Law as well as on the new Article 1252 of the French Civil Code-which gives the judge the power to order measures to cease or prevent environmental damage- and sought a court order requiring Total to 'take adequate measures to prevent the risks arising from its activities, by drastically reducing its greenhouse gas emissions' [44]. The company challenged the jurisdiction of civil courts to hear the dispute and claimed that it should be brought before the commercial courts. On the 11th of February 2021, the Tribunal Judiciaire de Nanterre confirmed its jurisdiction to hear the claim and affirmed that the claimants as 'non-traders' had the options to choose to bring their claim before the civil courts or the commercial courts [46]. The case is still on-going. 
These growing expectations in relation to the prevention of dangerous climate change are intrinsically connected to the due diligence expectations in terms of mitigation.

\subsection{Risk-Based Due Diligence and Mitigation}

In relation to the second facet-the mitigation side-risk-based due diligence entails the need for companies to put in place climate mitigation strategies to avoid human rights and environmental harms in the future and contribute to the green transition. However, the transition to low-carbon ('green') energy production is not without complications with regard to human rights impacts for people living now. Insofar as mitigation strategies can also have adverse impacts on human rights and, in particular, of the human rights of workers and communities, risk-based due diligence also requires companies to identify and address the adverse impacts that may arise out of such mitigation strategies in order to contribute to the fair transition.

\subsubsection{The Dilemma of a Fair Transition}

Green energy production involves several activities which are well-known in other contexts to frequently involve risks to human rights and/or the environment. Mining, industrialized agriculture and projects involving lands used by indigenous peoples or other communities do not magically become safer for workers and pose fewer risks to human rights and the environment, simply because the objective is laudable and the production needed for green energy. As in any other business activity, due diligence is an important process for business enterprises involved in green energy to identify and manage harmful impacts. This involves companies in energy production, as well as those in their supply chain and those that provide finance for the activities.

Protests, court cases and documented conflicts in several countries demonstrate that the quest for bio-fuel raw-materials, low-carbon renewable energy facilities, transition minerals (such as coltan, zink, copper required for solar panels, lithium, wind mills and energy storage) and land for bio-fuels crops and renewable energy production places host communities and their human rights under pressure $[47,48]$. Human rights risks related to transition-related natural resources are already well-documented, e.g., [49-56].

The risks of impacts on humans that result from climate change mitigation are covered by terms such as fair transitions, climate justice and energy justice. Scholars and other actors within these fields claim that mitigation practices should not pose imbalanced harm or risks, or leave those affected unable to fully participate in the decision-making or planning that impact their communities [15]. The basic idea is that the transition should be fair in not creating disproportionate burdens on some individuals or groups, in particular those that are already vulnerable.

The preambles to the Agenda 2030 and the Paris Climate Change Agreement note that the transition to a comprehensively sustainable low-carbon economy must be accomplished with respect for social impacts, in particular human rights. The implementation provisions for the Agenda 2030, including SDG 17 on global partnerships, explicitly refer to the UNGPs and therefore implicitly to due diligence.

Yet, reading the Agenda 2030 in the context of the Paris Climate Change Agreement raises potential dilemmas concerning a 'fair transition' to a green economy with respect for human rights [4]. In particular, this concerns human rights responsibilities of companies in the context of the speedy implementation of urgent measures to mitigate climate change that may at the same time involve adverse human rights impacts for local communities and other stakeholders affected by green energy infrastructures and the related rawmaterials production.

Applying the term 'just transition', the Paris Agreement explicitly recognises the human implications for those working in carbon-based energy sectors. However, a fair transition is a wider concept than a 'just transition', which mainly refers to the need for re-training and other measures to enable workers in the oil, gas and coal industries to retain employment following the transition to new forms of energy. 


\subsubsection{The Pertinence of Risk-Based Due Diligence to Advance Fair Transitions}

Mineral sourcing for renewable energy technology and siting of renewable energy infrastructure are just two examples where green economic transitions may provoke negative impacts and social conflicts within local communities [56,57]. The production of bio-fuel, including industrialised agri-culture and the process of acquiring land from small-scale farmers for such agri-industry is another example. While such agri-industry is particularly common in the global South [58], hydro-power projects are provoking protests over rights and access to water and land in several Arctic countries [59]. Where Sámi reindeer herders, members of Europe's Northernmost Indigenous people, have lodged cases with courts in Sweden, Norway or Finland, the tendency is that rolling out wind farms is prioritized over the cultural human rights of the Sámi [60]. Despite relatively high levels of formal guarantees of consultation and public participation in decisions with environmental impacts in environmental and social impact assessment legislation in the Nordics [61,62], the substantive outcomes of consultation processes suggest deep levels of dissatisfaction and frustration with the quality and results of actual participation.

As the business sector is involved in the development of green energy production or infrastructure, the problem is not just an issue of states' duties (such as to ensure consultation processes) but also of corporate responsibilities to respect human rights in line with the UNGPs and other business governance frameworks referencing riskbased due diligence. This includes rights to land, water or health, to involvement in decision-making affecting a person's life, and the right to free, prior and informed consent (FPIC). In this respect, the rights to participate and have access to information are key to effective risk-based due diligence [16] and entail that companies must ensure a meaningful engagement with affected stakeholders across the whole risk-based due diligence process. This means that companies should hear directly from people who have already been or may be impacted by climate-related impacts of their activities as well as those who have been or may be impacted by the actual and potential climate mitigation However, it is important to acknowledge the specificities of carrying out due diligence in relation to climate change and in particular the identification of potentially affected stakeholders. Indeed, climate change can impact virtually everyone on the planet, including future generations. As a result, the identification of the rights-holders that the company is to consult is not an easy task and may require a specific focus on those at heightened risk. Indeed, the human rights principles of equality and non-discrimination requires for climate action to address and remedy the disproportionate impacts of climate change on the most marginalized [16]. As a result, as part of their risk-based due diligence exercise, companies should pay special attention to individuals and communities who are disproportionately affected by both the climate-related impacts of their activities as well as the potential human rights impacts of their climate mitigation measures on the groups that are at heightened risk of vulnerability or marginalization. This is illustrated by a specific instance filed before the OECD NCPs of Sweden and Norway [63]. Comprised of indigenous Sámi, a reindeer herding collective in the Jijnjevaerie village in the border area of Sweden and Norway was concerned with the adverse impact on their traditional reindeer herding that would result from a new wind power plant planned by energy company Statkraft. They lodged a complaint with the OECD NCPs of Sweden and Norway concerning whether Statkraft had taken account of the interests of the Saami village and respected the human rights of the villagers, including with regard to consultation. They acknowledged that Statkraft had consulted with the community during the planning stages of the wind power plant but contended that 'meaningful engagement' had not taken place. The village alleged non-observance of the right of indigenous peoples to free, prior and informed consent (FPIC) under the ILO (1989) convention 169, which relates to human rights but is not an ILO fundamental convention. Even though the NCPs did not find that Statkraft had failed to observe the OECD Guidelines, they nonetheless recommended that the company upscale their consideration of Indigenous people's rights [63]. The NCPs emphasized that that ILO convention 169 is of particular relevance in indigenous or tribal areas. This highlighted 
that companies should consider whether their operational context makes it relevant to go beyond the minimum baseline for due diligence set by the UNGPs (the international bill of human rights and ILO core labour standards)

By referring to consultation and involvement of those affected, the statement is grounded in the recognition that the impact assessment must take account of the specific impacts on specific people, given the context of operations [17]. In this respect, inspired by the UNGPs and by the ILO Convention 169 but applying the approach in a wider context, the OECD Guidelines emphasize that companies must engage with relevant stakeholders in order to provide meaningful opportunities for their views to be taken into account in relation to planning and decision making for projects or other activities that may significantly impact local communities [6].

Meaningful stakeholder engagement and other elements of risk-based due diligence will not solve the dilemma on how to obtain a speedy but fair transition, but may help provide an informed basis for decisions to be taken and to be followed up. Moreover, through the exercise of leverage, down-stream companies such as energy buyers (power providers) can work with upstream companies to influence their decisions and practices, build capacity to undertake due diligence and develop strong practices of involvement of stakeholders. Similarly, institutional investors and other finance providers can exercise influence through active ownership or other such modalities in order to help direct companies they invest in to exercise due diligence for their own activities and throughout their value chains. Importantly, if well thought through, this can also cascade through the value chain so that the process of due diligence becomes an increasingly integrated and common practice in the value chain for a particular resource or energy product, even if transmitted through multiple partners. In this respect, statements from NCPs have clarified that the risk-based due diligence expectations apply to investors, whether majority or minority investors $[38,63,64]$.

In this context, the SDGs hold potential for a fair transition based on the exercise of due diligence. By explicitly targeting governments and implicitly addressing business enterprises, paragraph 67 's reference to the UNGPs offers the principled basis on which a fair transition can progress when business activities are involved. Paragraph 67 notes that business involvement in SDG implementation (such as SDG 7 or SDG 13) must not cause harm. Referencing the UNGPs, it implicitly calls on business enterprises to exercise risk-based due diligence and therefore also to ensure meaningful stakeholder engagement as part of the process to identify and manage their human rights risks. However, that potential will only become realized if all involved recognize that risk-based due diligence for human rights and the environment, including meaningful stakeholder engagement, is not limited to compliance with rules and requirements set by governments. The quality of the process is defined not by formal requirements but by what is needed for the substantive aim of identifying actual or potential impacts from the perspective of those at risk, and taking adequate responses to prevent risks or mitigate and remedy harm that has already occurred. Such adequate responses may also relate to remediation.

\subsection{Risk-Based Due Diligence and Remediation}

The UNGPs provide that in order to meet their responsibility to respect human rights, companies should have in place 'processes to enable the remediation of any adverse impacts they cause or to which they contribute' [18]. Although the UNGPs discuss remediation separately from human rights due diligence, it is also an important part of human rights due diligence as part of the requirement for companies to take action once they have identified actual or potential adverse impacts.

\subsubsection{Due Diligence and Access to Remedy}

The third facet or risk-based due diligence-the remediation side-rests on the right to effective access to remedy which is core to the international human rights system, and constitutes the third pillar of the UNGPs [16]. Access to remedy is envisaged in the UNGPs 
as a joint responsibility of the State and corporations. In relation the latter, the UNGPs provide that 'where business enterprises identify that they have caused or contributed to adverse impacts, they should provide for or cooperate in their remediation through legitimate processes' [18].

In relation to remediation for climate-related impacts, several challenges and specificities arise notably with respect to issues of standing, identification and attribution of the share of responsibility for each individual contributor and causation. For example, it may prove challenging to determine whether a specific company contributes or is directly linked to climate change and climate-related human rights and environmental adverse impacts. Nonetheless, the distinction between contribution and direct linkage has important implications in practice since it determines the type of due diligence which is required from the company but also whether the company is required to provide a remedy [18]. Indeed, where a company contributes to an impact, it should take the necessary steps to cease or prevent its contribution and mitigate any remaining impact, but also cooperate in remediation through legitimate processes, which involves providing for remediation proportionately to its share of responsibility in the harm [18]. In case of direct linkage on the other hand, the company is not normally required to provide remedy, but should merely seek to prevent or mitigate the impact and take appropriate action which will vary according to the extent of its leverage [18].

Whilst case law concerning the remediation of climate-related impacts of business activities is still in its infancy, the growing number of cases being filed against companies before domestic courts seek attest of the importance for companies to incorporate the remediation aspect in their risk-based due diligence exercise [39,42].

\subsubsection{Case-Law Expectations in Relation to Remediation}

Cases and complaint are increasingly calling into question the accountability of corporations for their climate-related impacts and requesting remediation. For instance, following a complaint by Greenpeace Southeast Asia, thirteen NGOs, and survivors of Typhoon Hainan, the Commission on Human Rights of the Philippines undertook a groundbreaking four-year global inquiry into the human rights impacts of climate change in the Philippines and the contribution of 47 Carbon Major companies in such impacts. The Commission found that the Carbon Majors played a clear role in anthropogenic climate change and its adverse impacts and should be held accountable for violations or threats of violations of Filipinos' rights (a) to life; (b) to the highest attainable standard of physical and mental health; (c) to food; (d) to water; (e) to sanitation; (f) to adequate housing; and (g) to self-determination resulting from the adverse impacts of climate change.' [14]. The recognition of such accountability and correlated need to participate in remediation efforts is an integral part of addressing climate change. In that sense, it is an essential part of the risk-based due diligence expectations. Remediation in the context of climate change can take different forms, which include the participation to the cost of preventative measures to address identified risks linked to climate change.

In this respect, in 2015 a climate change case was filed in Germany against German electricity supply company RWE by a Peruvian farmer from the village of Huaraz [65]. The claimant sustained that his house, which is located near a glacial lake, is at imminent risk of being flooded or destroyed as the glacier melts into the lake and claimed reparation corresponding to the cost of protecting his house from such risk [66]. In particular, the claimant alleged that RWE is partly responsible for the flooding risk, as it significantly contributed to global greenhouse gas emissions, and thus to climate change. Relying on available scientific evidence, the claimant argued that RWE's share in global total $\mathrm{CO}_{2}$ emissions from 1751 to 2010 was about $0.47 \%$ and that the company should therefore pay $0.47 \%$ of the preventative measures (such as drainage) required to avoid, or at least effectively mitigate the consequences of global warming in the claimant's area and protect his home [66]. On the 30th of November 2017, the Higher Regional Court of Hamm, ruled that it could proceed to hear the case and enter into the evidentiary stage [65]. The 
court also stated that the alleged threat to the claimant's property was attributable to the defendant's actions, since the starting point of the chain of causation was 'the role of the energy companies' operations as an active (contributory) cause of the flood risk' [65]. The case is currently on-going.

\section{Conclusions}

The UNGPs and their policy predecessor, the UN 'Respect, Protect, and Remedy' Framework (UN 2008) do not explicitly address climate change. This may reflect the fact that the global debate on climate change was less advanced at the time when those documents were adopted.

However, given the role of companies as one of the main drivers of climate change, they are expected to play an active role in combating climate change and reducing their greenhouse gas emissions.

This is recognised in recent case law and other grievances, as reviewed above. In particular, the Dutch court ruling in the case against Shell expresses clear expectations for companies in this respect, in order to deliver on their duty of care.

However, the discussions on corporate due diligence and climate change tends to overlook that adverse human rights impacts can also arise out of climate mitigation as well as core activities for companies in the green energy sector. Green energy production is a crucial element in the transition to low-carbon societies, yet the production facilities as well as the production of raw materials and transitions minerals for these frequently cause adverse human rights impacts that especially affect local communities. We argue that risk-based due diligence is also pertinent for companies in this sector to identify risks of harmful human rights impacts and address them. In this respect, special attention should be paid to vulnerable individuals and communities who are disproportionately affected by both the climate-related impacts of business activities as well as the human rights impacts resulting from business activities aiming to contribute to climate change mitigation.

In this paper, we have argued that, throughout its three facets-prevention, mitigation and remediation-, risk-based due diligence in relation to climate change can provide a useful tool for companies to identity, prevent, address and remediate their climate-related impacts in a holistic way which takes into consideration their implications for the human rights of rights-holders as well as for the environment in and of itself.

In addition, the case-law review suggests that the social expectations for companies to identify, prevent, address and remediate their climate change impacts and their implications for human rights and the environment are gradually being crystallised into legally binding duties. This trend is also being confirmed by parallel regulatory developments which are increasingly turning soft law due diligence expectations into binding duties covering human rights, the environment and climate change.

Author Contributions: Conceptualization; methodology; investigation; writing-original draft preparation; writing-review and editing, C.B. and K.B. Both authors have read and agreed to the published version of the manuscript.

Funding: This research received no external funding.

Institutional Review Board Statement: Not applicable.

Informed Consent Statement: Not applicable.

Conflicts of Interest: The authors declare no conflict of interest. 


\section{References}

1. IPCC. Global Warming of $1.5^{\circ} \mathrm{C}$. An IPCC Special Report on the Impacts of Global Warming of $1.5^{\circ} \mathrm{C}$ above Pre-Industrial Levels and Related Global Greenhouse Gas Emission Pathways, in the Context of Strengthening the Global Response to the Threat of Climate Change, Sustainable Development, and Efforts to Eradicate Poverty; Masson-Delmotte, V., Zhai, P., Pörtner, H.-O., Roberts, D., Skea, J., Shukla, P.R., Pirani, A., Moufouma-Okia, W., Péan, C., Pidcock, R., et al., Eds.; World Meteorological Organisation (WMO): New York, NY, USA; The United Nations Environmental Programme (UNEP): Geneva, Switzerland, 2018.

2. OHCHR. Analytical Study on the Relationship between Climate Change and the Human Right of Everyone to the Enjoyment of the Highest Attainable Standard of Physical and Mental, A/HRC/32/23. 2016. Available online: https://digitallibrary.un.org/ record/841798/? ln=fr\#record-files-collapse-header (accessed on 20 August 2021).

3. UN. Transforming Our World: The 2030 Agenda for Sustainable Development; UN Doc A/RES/70/1; UN: New York, NY, USA, 2015. Available online: https://www.un.org/en/development/desa/population/migration/generalassembly/docs/globalcompact/ A_RES_70_1_E.pdf (accessed on 20 August 2021).

4. UN. Framework Convention on Climate Change-Conference of the Parties: Adoption of the Paris Agreement; UN Doc. FCCC/CP/2015/ L.9/Rev.1; UN: New York, NY, USA, 2015. Available online: https://unfccc.int/resource/docs/2015/cop21/eng/109r01.pdf (accessed on 20 August 2021).

5. Smit, L.; Alogna, I. Human Rights Due Diligence for Climate Change Impacts: Webinar Series Report. January 2020. 2021. Available online: https://www.biicl.org/documents/125_hrdd_for_climate_change_impacts_webinar_series_report_8_jan_20 20.pdf (accessed on 21 August 2021).

6. OECD. Guidelines for Multinational Enterprises. 2011. Available online: http://dx.doi.org/10.1787/9789264115415-en (accessed on 21 August 2021).

7. Buhmann, K. Public regulators and CSR: The 'Social Licence to Operate' in recent United Nations instruments on Business and Human Rights and the juridification of CSR. J. Bus. Ethics 2016, 136, 699-714. [CrossRef]

8. Rockström, J.; Steffen, W.; Noone, K.; Persson, Å.; Chapin, F.S., III; Lambin, E.; Lenton, T.M.; Scheffer, M.; Folke, C.; Schellnhuber, H.; et al. Planetary boundaries: Exploring the safe operating space for humanity. Ecol. Soc. 2009, 14, 32-65. [CrossRef]

9. Gerber, P.J.; Steinfeld, H.; Henderson, B.; Mottet, A.; Opio, C.; Dijkman, J.; Falcucci, A.; Tempio, G. Tackling Climate Change Through Livestock-A Global Assessment of Emissions and Mitigation Opportunities; Food and Agriculture Organization of the United Nations (FAO): Rome, Italy, 2013. Available online: http:/ / www.fao.org/3/i3437e/i3437e.pdf (accessed on 20 August 2021).

10. Heede, R. Tracing anthropogenic carbon dioxide and methane emissions to fossi fuel and cement producers, 1854-2010. Clim. Chang. 2014, 122, 229-241. [CrossRef]

11. UN. Report of the Special Rapporteur, Philp Alston, on Extreme Poverty and Human Rights, 'Climate Change and Poverty', 17 July 2019, A/HRC/41/39. 2019. Available online: https://documents-dds-ny.un.org/doc/UNDOC/GEN/G19/218/66/PDF/ G1921866.pdf?OpenElement (accessed on 20 August 2021).

12. United Nations Framework Convention on Climate Change. 1992. Available online: https://unfccc.int/resource/docs/convkp/ conveng.pdf (accessed on 20 August 2021).

13. IPCC. Climate Change 2007: Synthesis Report. Contribution of Working Groups I, II and III to the Fourth Assessment; Report of the Intergovernmental Panel on Climate Change; Core Writing Team, Pachauri, R.K., Reisinger, A., Eds.; IPCC: Geneva, Switzerland, 2007. Available online: https:/ / www.ipcc.ch/site/assets/uploads/2018/02/ar4_syr_full_report.pdf (accessed on 20 August 2021).

14. IPCC. Working Group I report, Climate Change 2021: The Physical Science Basis. Contribution of Wokring Group I to the Sixth Assessment; Report of the Intergovernmental Panel on Climate Change. Available online: https://www.ipcc.ch/report/ar6/wg1 /downloads/report/IPCC_AR6_WGI_Full_Report.pdf (accessed on 20 August 2021).

15. OHCHR, Frequently Asked Questions on Human Rights and Climate Change. Available online: https://www.ohchr.org/ Documents/Publications/FSheet38_FAQ_HR_CC_EN.pdf (accessed on 20 August 2021).

16. Committee on Economic, Social and Cultural Rights (2018), 'Committee Releases Statement on Climate Change and the Covenant, 8 October 2018. Available online: https:/ / www.ohchr.org/en/NewsEvents/Pages/DisplayNews.aspx?NewsID=23691\&LangID= E (accessed on 20 August 2021).

17. UN. Protect, Respect and Remedy: A Framework for Business and Human Rights; Report of the Special Representative of the SecretaryGeneral on the Issue of Human Rights and Transnational Corporations and Other Business Enterprises; Ruggie, J., Ed.; UN Doc. A/HRC/8/5; UN: New York, NY, USA, 2008. Available online: https://undocs.org/en/A/HRC/8/5 (accessed on 20 August 2021).

18. UN. Guiding Principles on Business and Human Rights: Implementing the United Nations "Protect, Respect and Remedy" Framework; UN Doc. A/HRC/17/31; UN: New York, NY, USA, 2011. Available online: https://www.ohchr.org/documents/publications/ guidingprinciplesbusinesshr_en.pdf (accessed on 20 August 2021).

19. OHCHR. OHCHR Response to Request from BankTrack for Advice Regarding the Application of the UN Guiding Principles on Business and Human Rights in the Context of the Banking Sector. 2017. Available online: https://www.ohchr.org/Documents / Issues/Business/InterpretationGuidingPrinciples.pdf (accessed on 20 August 2021).

20. Ruggie, J.G.; Rees, C.; Davis, R. Ten years after: From the UN Guiding Principles to multi-fiduciary obligations. Bus. Hum. Rights J. 2021, 6, 1-19. [CrossRef] 
21. Macchi, C.; Bright, C. Hardening Soft Law: The Implementation of the Human Rights due Diligence Requirements in Domestic Legislations. In Legal Sources in Business and Human Rights: Evolving Dynamics in International and European Law; Buscemi, M., Lazzerini, N., Magi, L., Russo, D., Eds.; Brill: Leiden, The Netherlands, 2020; pp. 218-247.

22. Loi No. 2017-399 du 27 Mars 2017 Relative au Devoir de Vigilance des Sociétés Mères et des Entreprises Donneuses D’ordre. Available online: https:/ / www.legifrance.gouv.fr/affichTexte.do?cidTexte=JORFTEXT000034290626\&categorieLien=id (accessed on 20 August 2021).

23. The Netherlands Child Labour Due Diligence Act 2019. On this Law, See for Instance Mvoplatform, Update: Frequently Asked Questions about the New Dutch Child Labour Due DIligence Law, 3 June 2019. Available online: https:/ / www.mvoplatform.nl/ en/frequently-asked-questions-about-the-new-dutch-child-labour-due-diligence-law / (accessed on 20 August 2021).

24. Dutch Bill for Responsible and Sustainable International Business Conduct. Unofficial Translation. Available online: https: //www.mvoplatform.nl/en/wp-content/uploads/sites/6/2021/03/Bill-for-Responsible-and-Sustainable-International-BusinessConduct-unofficial-translation-MVO-Platform.pdf (accessed on 20 August 2021).

25. Norwegian Act on business transparency and work with fundamental human rights and decent work ('Transparency Act'). Available online: https://www.regjeringen.no/contentassets/c33c3faf340441faa7388331a735f9d9/no/pdfs/prp2020202101500 00dddpdfs.pdf (accessed on 20 August 2021).

26. Triponel, A. What is the new Norwegian Human Rights and Decent Work Due Diligence Law?, Triponel Consulting, 14 June 2021. Available online: https://triponelconsulting.com/2021/06/14/what-is-the-new-norwegian-human-rights-and-decentwork-due-diligence-law/ (accessed on 20 August 2021).

27. Gesetz über die Unternehmerischen Sorgfaltspflichten in Lieferketten. 03. März 2021. Available online: https://www.bmas.de/ SharedDocs/Downloads/DE/Gesetze/Regierungsentwuerfe/reg-sorgfaltspflichtengesetz.pdf (accessed on 20 August 2021).

28. Bright, C. Mapping human rights due diligence regulations and evaluating their contribution in upholding labour standards in global supply chains. In Decent Work in Globalised Economy: Lessons from Public and Private Initiatives; Delautre, G., Manrique, E.E., Fenwick, C., Eds.; ILO: Geneva, Switzerland, 2021; pp. 75-108. Available online: https://www.ilo.org/wcmsp5/groups/public/ ---dgreports/---dcomm/---publ/documents/publication/wcms_771481.pdf (accessed on 20 August 2021).

29. European Parliamen. European Parliament Resolution of 10 March 2021 with Recommendations to the Commission on Corporate Due Diligence and Corporate Accountability (2020/2129(INL)); European Parliamen: Brussels, Belgium, 2021.

30. IFC. Performance Standards on Environmental and Social Sustainability. 2012. Available online: https://www.ifc.org/wps/wcm/ connect/24e6bfc3-5de3-444d-be9b-226188c95454/PS_English_2012_Full-Document.pdf?MOD=AJPERES\&CVID=jkV-X6h (accessed on 20 August 2021).

31. OECD. Green financing: Challenges and opportunities in the transition to a clean and climate-resilient economy. OECD J. Financ. Mark. Trends 2017, 2, 63-78. [CrossRef]

32. EU. Regulation of the European Parliament and the Council (EU) 2019/2088 of 27 November 2019 on Sustainability Related Disclosures in the Financial Services Sector; EUJ L 317/1; UN: New York, NY, USA, 2019.

33. OECD. OECD Due Diligence Guidance for Responsible Business Conduct; OECD: Paris, France, 2018.

34. Buhmann, K. Analyzing OECD National Contact Point statements for guidance on human rights due diligence: Method, findings and outlook. Nord. J. Hum. Rights 2018, 36, 390-410. [CrossRef]

35. World Benchmarking Alliance. Corporate Human Rights Benchmark-Across Sectors: Agricultural Products, Apparel, Automotive Manufacturing, Extractives \& ICT Manufacturing 2020 Key Findings. 2020. Available online: https: / /assets.worldbenchmarkingalliance.org/app/uploads/2020/11/WBA-2020-CHRB-Key-Findings-Report.pdf (accessed on 20 August 2021).

36. World Benchmarking Alliance. Accessing a just transition: Draft methodology-Methodology for public consultation. March 2021. Available online: https://assets.worldbenchmarkingalliance.org/app/uploads/2021/03/WBA-draft-just-transitionmethodology_final.pdf (accessed on 20 August 2021).

37. Bourguignon, D. The Precautionary Principle: Definitions, Applications and Governance, European Parliamentary Research Services, December 2015. Available online: https://www.europarl.europa.eu/RegData/etudes/IDAN/2015/573876/EPRS_ IDA(2015)573876_EN.pdf (accessed on 20 August 2021).

38. Dutch National Contact Point (NCP) (2019), 'Final Statement', Oxfam Novib, Greenpeace Netherlands, BankTrack and Friends of the Earth Netherlands (Mileudefensie) versus ING, 19 April 2019. Available online: https://www.oecdwatch.org/wpcontent/uploads/sites/8/dlm_uploads/2021/03/Final\%20Statement\%20NGOs\%20vs\%20ING\%202019-04-19.pdf (accessed on 20 August 2021).

39. Macchi, C. The Climate Change Dimension of Business and Human Rights: The Gradual Consolidation of a Concept of Climate Change Due Diligence. Bus. Hum. Rights J. 2021, 6, 93-119. [CrossRef]

40. The Hague Court of Appeal, The State of the Netherlands vs. Urgenda Foundation, 200.178.245/01, 9 October 2018. Available online: http: / / climatecasechart.com/climate-change-litigation/wp-content/uploads/sites/16/non-us-case-documents / 2018 /20181009_2015-HAZA-C0900456689_decision-4.pdf (accessed on 20 August 2021). 
41. Communication to the Committee on the Rights of the Child in the case of Chiara Sacchi, Caratina Lorenzo, Iris Duquene, Raina Ivanova, Ridhima Pandey, David Ackley, III, Ranton Anjain, Litokne Kabua, Deborah Adegbile, Carlos Manuel, Ayakha Melithafa, Greta Thunberg, Raslen Jbeili, Carl Smith and Alexandria Villaseños v. Argentina, Brazil, France, Germany and Turkey, Submitted under Article 5 of the Third Optional Protocol to the United Nations Convention on the Rights of the Child, 23 September 2019. Available online: https: / / earthjustice.org/sites/default/files/files/2019.09.23-crc-communication-sacchi-et-alv.-argentina-et-al-redacted.pdf (accessed on 20 August 2021).

42. The Hague District Court, Vereniging Milieudefensie and al. v. Royal Dutch Shell, C/09/571832, 26 May 2021. Available online: https:/ / uitspraken.rechtspraak.nl/inziendocument?id=ECLI:NL:RBDHA:2021:5339 (accessed on 20 August 2021).

43. Bueno, N.; Bright, C. Implementing Human Rights Due Diligence through Corporate Civil Liability. Int. Comp. Law Q. 2020, 69, 789-818. [CrossRef]

44. Sherpa. Climate Change Litigation against Total: A First Victory for the NGOs and Local Authorities, 11 February 2021.2021. Available online: https: / www.asso-sherpa.org/ climate-change-litigation-against-total-a-first-victory-for-the-ngos-and-localauthorities (accessed on 20 August 2021).

45. Brabant, S.; Savourey, E. All Eyes on France-French Vigilance Law First Enforcement Cases (1/2): Current Cases and Trends. 2017. Available online: https://www.cambridge.org/core/blog/2020/01/24/all-eyes-on-france-french-vigilance-law-firstenforcement-cases-1-2-current-cases-and-trends/\#_edn13 (accessed on 20 August 2021).

46. Tribunal Judiciaire de Nanterre, 1ère Chambre, Ordonance de Mise en état, Association Notre Affaire à Tous et al. v. Total, 11 February 2021. Available online: https:/ / www.asso-sherpa.org/wp-content/uploads/2021/02/110221-MINUTE-Total-climatcompetence.pdf (accessed on 20 August 2021).

47. Koning, A.; Kleijn, R.; Huppes, G.; Sprecher, B.; van Engelen, G.; Tukker, A. Metal supply constraints for a low-carbon economy? Resour. Conserv. Recycl. 2018, 129, 202-208. [CrossRef]

48. Scarlat, N.; Dallemand, J.-F.; Monforti-Ferrario, F.; Nita, V. The role of biomass and bioenergy in a future bioeconomy: Policies and facts. Environ. Dev. 2015, 15, 3-34. [CrossRef]

49. Rodríguez-Labajos, B.; Özkaynak, B. Environmental justice through the lens of mining conflicts. Geoforum 2017, 84, 245-250. [CrossRef]

50. Lujala, P.; Rustad, S.A. High-value natural resources: A blessing or a curse for peace? Sustain. Dev. Law Policy 2011, 12, 19-22, 56-57.

51. Haalboom, B. The intersection of corporate social responsibility guidelines and indigenous rights: Examining neoliberal governance of a proposed mining project in Suriname. Geoforum 2012, 43, 969-979. [CrossRef]

52. Gillespie, P. Participation and power in Indonesian oil palm plantations. Asia Pac. Viewp. 2012, 53, 254-271. [CrossRef]

53. Rist, L.; Feintrenie, L.; Levang, P. The livelihood impacts of oil palm: Smallholders in Indonesia. Biodivers. Conserv. 2010, 19, 1009-1024. [CrossRef]

54. Burnley, C. Natural resources conflict in the Democratic Republic of the Congo: A question of governance. Sustain. Dev. Law Policy 2011, 12, 7-11, 52-53.

55. Escobar, A. Difference and Conflict in the Struggle over Natural Resources: A political ecology framework. Development 2006, 49, 6-13. [CrossRef]

56. Montague, D. Stolen goods: Coltan and conflict in the Democratic Republic of Congo. SAIS Rev. 2002, 22, 103-118. [CrossRef]

57. Vanclay, F.; Hanna, P. Principles to gain a social licence to operate for green initiatives and biodiversity projects. Curr. Opin. Environ. Sustain. 2017, 29, 48-56. [CrossRef]

58. Cotula, L.; Berger, T. Trends in Global Land Use Investment: Implications for Legal Empowerment, International Institute for Environment and Development (IIED). 2017. Available online: http:/ / pubs.iied.org/12606IIED/ (accessed on 20 August 2021).

59. Buhmann, K.; Bowles, P.; Cambou, D.; Skjervedal, A.S.H.; Stoddart, M. Towards socially sustainable renewable energy projects through involvement of local communities: Normative aspects and practices on the ground. In Renewable Economies in the Arctic: A State of Knowledge; Natcher, D., Koivurova, T., Eds.; Routledge: Milton Park, UK, 2021.

60. Cambou, D.; Sandström, P.; Skarin, A.; Borg, E. Reindeer husbandry vs. wind energy: Analysis of the Pauträsk and Norrbäck court decisions in Sweden. In Indigenous Peoples, Natural Resources and Governance: Interactions and Agencies; Tennberg, M., Broderstad, E.G., Hernes, H.K., Eds.; Routledge: Abingdon, UK, 2021.

61. Hansen, A.M.; Vanclay, F.; Croal, P.; Skjervedal, A.S.H. Managing the social impacts of the rapidly-expanding extractive industries in Greenland. Extr. Ind. Soc. 2016, 3, 25-33. [CrossRef]

62. Nenasheva, M.; Bickford, S.; Lesser, P.; Koivurova, T.; Kankaanpaa, P. Legal tools of public participation in the Environmental Impact Assessment process and their application in the countries of the Barents Euro-Arctic Region. Barents Stud. 2015, 1, 13-35.

63. Norway NCP, Jijnjevaerie Saami Village vs. Statkraft AS: Final Statement. 2016. Available online: https://www.oecdwatch.org/ complaint/jijnjevaerie-saami-village-vs-statkraft/ (accessed on 20 August 2021).

64. NCP of Norway (2013) Complaint from Lok Shakti Abhiyan, Korean Transnational Corporations Watch, Fair Green and Global Alliance, and Forum for Environment and Development vs. POSCO/South Korea, ABP/APG (Netherlands) and NBIM (Norway) (27 May 2013). Available online: https:/ /www.oecdwatch.org/complaint/lok-shakti-abhiyan-et-al-vs-government-pensionfund-global/ (accessed on 20 August 2021). 
65. Higher Regional Court of Hamm, Indicative Court Order and Order for the Hearing of Evidence in the Legal Matter of Mr. Saúl Ananías Luciano Lliuya, Provincia de Huaraz, Peru v. RWE, 20 November 2017, Unauthorised Translation Provided by Germanwatch e.V. Available online: https://germanwatch.org/sites/default/files/announcement/20812.pdf (accessed on 20 August 2021).

66. Marx, A.; Bright, C.; Wouters, J. Access to Legal Remedy for Victims of Corporate Human Rights Abuses in Third Countries Study Requested by the European Parliament's Sub-Committee on Human Rights (Co-Authored with Prof. Axel Marx and Jan Wouters from the Leuven Centre for Global Governance Studies). Available online: http:/ / www.europarl.europa.eu/RegData / etudes/STUD/2019/603475/EXPO_STU(2019)603475_EN.pdf (accessed on 20 August 2021). 